\title{
Analisis Pengaruh Pengetahuan Pajak dan Tingkat Pendidikan Terhadap Kepatuhan Wajib Pajak Orang Pribadi dalam Pembayaran Pajak Penghasilan (PPh) di KPP Pratama Palembang Seberang Ulu
}

\author{
Shanty Ramadhan ${ }^{1}$, Mohammad Aryo Arifin ${ }^{2}$, Nyayu Ully Aulina ${ }^{3}$ \\ ${ }^{1}$ Fakultas Ekonomi dan Bisnis Universitas PGRI Palembang, shantyramadhan123@gmail.com \\ ${ }^{2}$ Fakultas Ekonomi dan Bisnis Universitas PGRI Palembang, aryo.83arifin@gmail.com \\ ${ }^{3}$ Politeknik Darussalam Palembang, nyayuullypoliteknikdarussalam@gmail.com
}

\begin{abstract}
ABSTRAK
Penelitian ini merupakan penelitian yang bersifat kausal komparatif dengan pendekatan kuantitatif. Pengambilan sampel dilakukan dengan teknik insidental sampling dengan 100 responden. Metode pengumpulan data menggunakan metode kuesioner dalam bentuk pertanyaan tertutup. Sebelum kuesioner dibagikan dilakukan uji coba istrumen untuk diuji validitas dan reliabilitasnya agar memperoleh hasil yang sesuai dengan fakta. Selanjutnya teknik analisis data dilakukan dengan uji asumsi klasik yaitu uji normalitas, uji heteroskedastisitas, dan uji multikolinearitas sebagai syarat uji regresi untuk pengujian hipotesis. Uji hipotesis yang digunakan adalah analisis regresi linier berganda. Hasil dari penelitian ini menunjukkan bahwa Pengetahuan Perpajakan, Tingkat pendidikan dan kepatuhan wajib pajak berpengaruh singnifikan $0.00<0,05$ akan tetapi nilai konstanta dari Pengetahuan Pajak bernilai negatif hal ini disebabkan oleh beberapa faktor yang membuat hasil dari pengetahuan pajak berpengaruh negatif.
\end{abstract}

Kata Kunci: Pengetahuan Pajak, Tingkat Pendidikan, dan Kepatuhan Wajib Pajak Orang Pribadi.

\begin{abstract}
This research is a comparative causal research with a quantitative approach. Sampling was done by incidental sampling technique with 100 respondents. The data collection method used a questionnaire method in the form of closed questions. Before the questionnaires were distributed, instrument trials were conducted to test their validity and reliability in order to obtain results in accordance with the facts. Furthermore, the data analysis technique was carried out using the classical assumption test, namely the normality test, heteroscedasticity test, and multicollinearity test as a regression test requirement for hypothesis testing. The hypothesis test used is multiple linear regression analysis.

The results of this study indicate that Tax Knowledge, education level and taxpayer compliance have a significant effect on $0.00<0.05$ but the constant value of Tax Knowledge is negative this is caused by several factors that make the results of tax knowledge have a negative effect.
\end{abstract}

Keywords: Tax Knowledge, Education Level, and Personal Taxpayer Compliance.

\section{A. PENDAHULUAN}

Sumber penerimaan negara berasal dari beberapa sektor, yang terdiri dari sektor internal maupun eksternal. Salah satu sumber penerimaan negara dari sektor internal adalah pajak. Pajak ialah iuran rakyat kepada kas negara berdasarkan Undang-undang sehingga dapat dipaksakan dengan tidak mendapat balasan jasa secara langsung dan merupakan salah satu sumber pembiayaan pembangunan nasional dalam rangka meningkatkan kesejateraan masyarakat (Lubis, 2018:1).

Pajak ialah sumber pembiayaan pembangunan nasional yang bertujuan untuk mewujudkan kesejahteraan seluruh rakyat dan sekaligus berusaha menjadikan bangsa indonesia menjadi bangsa yang mandiri. Disamping itu digunakan untuk membiayai pengeluaran rutin dan ekonomi masyarakat, oleh karena itu pemerintah berusaha semaksimal mungkin untuk mencapai target penerimaan pajak. Penentuan target penerimaan yang sangat tinggi dan terus meningkat secara signifikan dari

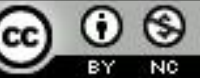


waktu ke waktu menunjukkan salah satu bukti, bahwa pajak merupakan primadona bagi sumber pendapatan negara.

Pemerintah tidak berhenti untuk melakukan intensifikasi dan ekstensifikasi dalam meningkatkan penerimaan dan pemungutan pajak. Usaha tersebut dapat dilakukan dengan cara memaksimalkan tugas dari Ditjen pajak maupun aparat pajak. Selain itu kegiatan intensifikasi dan ekstensifikasi ini juga membutuhkan peran aktif dari wajib pajak itu sendiri. Salah satu contohnya adalah meningkatkan pendapatakan pajak penghasilan.

Pajak penghasilan (PPh) ialah jenis pajak subjektif yang kewajiban pajaknya melekat pada subjek pajak yang bersangkutan, artinya kewajiban pajak tersebut dimaksudkan untuk tidak dilimpahkan kepada subjek pajak lainnya. Mengingat begitu banyaknya jenis pajak penghasilan, maka dalam penelitan ini peneliti membatasi hanya meneliti tentang Pajak Penghasilan Pasal 21 yakni pajak yang dipotong oleh pihak lain atas penghasilan berupa gaji, upah, honorarium, tunjangan, dan pembayaran lain dengan nama dan dalam bentuk apapun sehubungan dengan pekerjaan, jasa, atau kegiatan yang dilakukan oleh Wajib Pajak orang pribadi dalam negeri (Lubis, 2018:206).

Kepatuhan dan pengetahuan pajak yang tinggi dari Wajib Pajak itu sendiri dapat menimbulkan pengaruh penting dalam perubahan sistem pengaruh di Indonesia saat ini. Perubahan dalam penyempurnaan sistem pengaruh dari Official Assessment system menjadi Self Assessment system, dapat memberikan kepercayaan kepada wajib pajak untuk mendaftar, menghitung, membayar dan melaporkan kewajiban perpajakannya sendiri ke kantor pelayanan pajak (KPP).

Sistem Selft Assessment pada kenyataannya tidak berjalan begitu lancar, karena sebagian besar masyarakat atau wajib pajak kurang paham mengenai perpajakan. Di samping itu ada beberapa masyarakat yang tidak begitu peduli dengan pajak, sebab wajib pajak berpikir bahwa pembayaran pajak merugikan dirinya. Hal ini disebabkan oleh kurangnya pemahaman dan pengetahuan wajib pajak mengenai perpajakan. Melihat masalah ini, sebagian wajib pajak banyak memperoleh pengetahuan tentang pajak dari petugas pajak, ada yang memperolehnya dari radio, koran, internet, buku perpajakan, konsultan pajak, seminar pajak dan pelatihan pajak.

TABEL DATA WAJIB PAJAK YANG TERDAFTAR
DI KPP PRATAMA SEBERANG ULU TAHUN 2019
\begin{tabular}{|c|c|c|}
\hline No & Bulan & Jumlah Wajib Pajak \\
\hline 1 & Januari & 1,434 \\
\hline 2 & Februari & 1,355 \\
\hline 3 & Maret & 2,550 \\
\hline 4 & April & 1,224 \\
\hline 5 & Mei & 1,087 \\
\hline 6 & Juni & 935 \\
\hline 7 & Juli & 1,178 \\
\hline 8 & Agustus & 1,124 \\
\hline 9 & September & 1,584 \\
\hline 10 & Oktober & 1,507 \\
\hline 11 & November & 1,253 \\
\hline 12 & Desember & 1,826 \\
\hline Sumber : KPP Pratama Palembang Seberang Ulu
\end{tabular}


Dilihat dari data jumlah wajib pajak diatas, maka dapat disimpulkan bahwa kepatuhan wajib pajak orang pribadi tahun 2019 masih belum berjalan secara optimal. Karena, ada tiga hambatan yang menyebabkan belum optimalnya penerimaan pajak diindonesia yaitu pertama; tingkat kepatuhan wajib pajak badan ataupun pribadi dalam pembayaran pajak masih sangat rendah; kedua, penerimaan pajak masih didominasi sektor formal dan besar; ketiga, kapasitas kelembagaan masih terbatas. Sehingga dari bulan januari sampai dengan desember penerimaan pajak menggunakan pekerjaan yang bersifat rutin dan insidental menyebabkan penerimaan pajak di KPP Pratama Palembang Seberang Ulu dari bulan ke bulan itu tidak tetap. Maksud dari bersifat rutin yakni dilakukan setiap waktu dan bersifat insidental yakni terjadi atau dilakukan hanya pada kesempatan atau waktu tertentu saja atau sewaktu-waktu.

Dalam prosedur perpajakan Wajib Pajak diharapkan dapat meningkatkan kepatuhan wajib pajak, dalam hal mendaftarkan diri untuk mendapatkan Nomor Pokok Wajib Pajak (NPWP). Wajib Pajak mendapatkan NPWP dengan melakukan administrasi dalam pelaporan dan penyampaian SPT masa dan tahunan. Serta dapat mengurangi risiko pembayaran pajak tidak tepat waktu. Untuk dapat mengukur seberapa besar pengaruh Wajib Pajak dalam kepatuhan Wajib Pajak itu sendiri dalam hal penyampaian dan pelaporan SPT secara benar dan tepat waktu. Sehingga target kepatuhan Wajib Pajak dalam pemenuhan keinginan yang dilakukan oleh pembayaran pajak dapat memberikan kontribusi bagi pembangunan.

Pengetahuan pajak ialah suatu informasi tentang perpajakan yang dapat digunakan oleh Wajib Pajak itu sendiri sebagai dasar untuk mengambil keputusan dan arah strategi yang berhubungan dengan pelaksanaan hak dan kewajiban dibidang perpajakan. Hasil penelitian terdahulu yang dilakukan oleh Hartini dan Sopian (2018) menunjukkan bahwa pengetahuan perpajakan berpengaruh positif dan signifikan terhadap kepatuhan wajib pajak, kesadaran wajib pajak berpengaruh baik dan tidak signifikan terhadap kepatuhan wajib pajak.

Tingkat pendidikan ialah sebuah kondisi atau tahapan dari jenjang pendidikan yang dilalui oleh seseorang dengan melewati pendidikan formal yang sudah ditetapkan oleh lembaga terkait berdasarkan kepada tingkat perkembangan peserta didik, tingkat kesulitan bahan pengajar, dan cara penyajian bahan pengajaran yang selanjutnya disahkan oleh departemen pendidikan. Tingkatan dari pendidikan formal yakni terdiri dari pendidikan dasar, pendidikan menegah, dan pendidikan tinggi. Pendidikan formal ini sangat diharapkan dari pemerintah. Namun, pemerintah tidak dapat melakukan tugas ini bila sendirian. Oleh karena itu, peran aktif dari semua masyarakat sangat dibutuhkan dalam mencerdaskan semua wajib pajak. Hasil penelitian yang dilakukan oleh Chandra (2017) yang menunjukkan bahwa pengetahuan perpajakan memiliki pengaruh positif dan singnifikan terhadap kepatuhan wajib pajak dan tingkat pendidikan tidak memiliki pengaruh positif dan singnifikan pada kepatuhan wajib pajak di KPP Pratama Medan Petisah.

\section{B. KAJIAN TEORI}

\section{Pengertian Pajak}

Pengertin pajak dan perpajakan menurut Undang-undang dan para ahli. Menurut Undang-undang Nomor 16 tahun 2009 tentang perubahan keempat atas Undang-undang Nomer 6 tahun 1983 tentang ketentuan umum dan tata cara perpajakan pasal 1 ayat 1 yang berbunyi, pajak adalah kontribusi wajib kepada negara yang terhutang oleh orang pribadi atau badan yang bersifat memaksa 
berdasarkan undang-undang dengan tidak mendapatkan imbalan secara langsung dan digunakan untuk keperluan Negara bagi sebesar-besarnya kemakmuran rakyat.

\section{Fungsi Pajak}

Menurut Lubis (2018:2), ada dua jenis fungsi pajak, yakni :

a. Fungsi Anggaran atau Sumber Keuangan Negara (Budgetair)

b. Fungsi Rengatur (Regularend)

\section{Sistem Pungutan Pajak}

Menurut Lubis (2018:11), Ada tiga sistem pemungutan pajak yaitu:

a. Official Assesment System.

b. Self Assesment System

c. Witholding System.

\section{Wajib Pajak (WP)}

Menurut UU No. 28 Tahun 2007 tentang ketentuan umum dan tata dan tata cara perpajakan pasal 1, bahwa yang dimaksud wajib pajak (WP) adalah orang pribadi atau badan, meliputi pembayaran pajak, potongan pajak, dan pemungut pajak yang mempunyai hak dan kewajiban perpajakan sesuai dengan ketentuan peraturan perundang-undangan perpajakan.

\section{Pajak Penghasilan (PPh)}

Pajak penghasilan (PPh) ialah jenis pajak subjektif yang kewajiban pajaknya melekat pada subjek pajak yang bersangkutan, artinya kewajiban pajak tersebut dimaksudkan untuk tidak dilibatkan kepada subjek pajak lainnya (Tmbooks, 2016:4).

Berdasarkan Pasal 2 ayat (1) UU Nomer 36 Tahun 2008, Subjek pajak dikelompokkan sebagai berikut :

a. Subjek Pajak Orang Pribadi

b. Warisan yang belum terbagi sebagai satu kesatuan mengantikan yang berhak

c. Badan

d. Bentuk Usaha Tetap (BUT)

\section{Pengetahuan Pajak}

Pengetahuan pajak adalah informasi pajak yang dapat digunakan wajib pajak sebagai dasar untuk bertindak, mengambil keputusan dan untuk menempuh arah atau strategi tertentu sehubungan dengan pelaksanaan hak atau kewajibannya dibidang perpajakan (Veronica Caroline, 2009:7).

\section{Indikator pengetahuan pajak}

Indikator dalam mengukur tingkat pengetahuan pajak yaitu :

1. pengetahuan mengenai Ketentuan Umum dan Tata Cara Perpajakan.

2. Pengetahuan mengenai Fungsi Perpajakan.

3. Pengetahuan mengenai Sistem Perpajakan di Indonesia.

\section{Tingkat pendidikan}

Menurut Undang-Undang Republik Indonesia pasal 1 Nomor 20 Tahun 2003 tentang Pendidikan Nasional, pengertian pendidikan adalah usaha sadar dan terencana untuk mewujudkan suasana belajar dan proses pembelajaran agar peserta didik secara aktif mengembangkan potensi dirinya untuk memiliki kekuatan spiritual keagamaan, pengendalian diri, kepribadian, kecerdasan, akhlak mulia, serta keterampilan yang diperlukan dirinya, masyarakat, bangsa dan Negara. 


\section{Indikator tingkat pendidikan}

Indikator Tingkat Pendidikan Menurut UU SISDIKNAS No. 20 (2003), Indikator tingkat pendidikan terdiri dari jenjang pendidikan, terdiri dari:

1. Pendidikan dasar

2. Pendidikan menengah

3. Pendidikan tinggi

\section{Macam-macam tingkat pendidikan}

1. Pendidikan dasar

2. Pendidikan menengah

3. Pendidikan tinggi

\section{Kepatuhan wajib pajak}

Menurut Siti Kurnia (2010:19), Kepatuhan perpajakan ialah keadaan dimana Wajib Pajak mampu memenuhi semua kewajiban perpajakan dan melaksanakan hak perpajakannya.

Kepatuhan Wajib Pajak dibagi menjadi :

1. Kepatuhan Formal

2. Kepatuhan material

\section{Indikator kepatuhan wajib pajak}

Empat indikator dalam mengukur kepatuhan wajib pajak adalah sebagai berikut :

1. Wajib pajak mendaftarkan diri untuk mendapatkan identitas.

2. Wajib Pajak mengisi dengan jujur, lengkap dan benar SPT sesuai ketentuan. Menyampaikan SPT ke KPP sebelum batas waktu terakhir.

3. Kepatuahan wajib pajak membayar tunggakan.

\section{METODE PENELITIAN}

Penelitian ini ditulis menggunakan metode penelitian kuantitatif. Menurut Sugiyono (2016:13), metode kuantitatif dapat diartikan sebagai metode penelitian yang berdasarkan pada filsafat positivisme digunakan untuk meneliti pada populasi atau sampel tertentu, teknik pengambilan sampel pada umumnya dilakukan secara random. Selama proses analisis, penulis menggunakan metode deskriptif dimana data yang dikumpulkan akan diproses dan dianalisis menggunakan proses SPSS kemudian akan didapat hasil yang akan menunjukkan pengaruh dari setiap variabel yang ada terhadap variabel lainnya. Selanjutnya ditarik kesimpulan.

Metode penelitian yang dapat digunakan antara lain:

Angket (Kuesioner)

Menurut Sugiyono (2017:192), kuesioner yakni suatu teknik pengumpulan data dimana partisipan dari responden untuk mengisi pertanyaan atau pernyataan kemudian setelah diisi dengan lengkap oleh responden kemudian menyerahkan atau mengembalikan pertanyaan itu kepada peneliti. Dalam metode penelitian ini peneliti menggunakan angket/kuesioner yang di bagikan kepada para responden yang dipilih secara acak ke Wajib Pajak yang ada di KPP Pratama Palembang Seberang Ulu. Pemilihan responden secara acak diharapkan dapat menggeneralisasi. Pembagian angket/kuesioner dilakukan oleh peneliti kepada Wajib Pajak orang pribadi di KPP Pratama Palembang Seberang Ulu. Selanjutnya peneliti memberikan penjelasan mengenai cara-cara pengisian kuesioner. Responden akan diberi waktu dan diminta untuk mengisi data sesuai dengan yang tercantum dalam kuesioner. Kuesioner ini bersifat tertutup. 
Selanjutnya kuesioner dikembalikan kepada peneliti dalam waktu yang telah ditentukan.

$>$ Dokumentasi

Dokumentasi yang peneliti gunakan dalam penelitian ini adalah data jumlah wajib pajak yang terdaftar tahun 2019 dan jumlah pendapatan yang diterima oleh kpp pratama palembang seberang ulu dari wajib pajak orang pribadi dalam pajak penghasilan tahun 2019, serta dokumentasi pada saat peneliti membagikan koesioner kepada responden yang ada di kpp.

\section{Variabel Penelitian}

Menurut Sugiyono (2017:63), Variabel penelitian adalah suatu hal yang berbentuk apa saja yang ditetapkan oleh peneliti untuk dipelajari sehingga diperoleh informasi tentang hal tersebut, kemudian dapat ditarik kesimpulannya.

Variabel dependen yang saling terkait merupahkan variabel yang dipengaruhi atau yang menjadi akibat, karena adanya variabel independen. Sedangkan variabel independen atau variabel bebas merupakan variabel yang mempengaruhi atau menjadi sebab timbulnya variabel dependen (terkait). Dengan demikian Variabel Dependen ( $Y$ ) dalam penelitian ini adalah Kepatuhan Wajib Pajak Orang Pribadi sedangkan Variabel Independen $(X)$ dalam Penelitian ini adalah Pengetahuan Pajak X1, Tingkat Pendidikan X2.

\section{Skala Pengukuran}

Skala pengukuran ialah tolak ukur yang dipakai dalam melakukan suatu penelitian. Penelitian ini menggunakan instrumen kuesioner atau angket. Data diambil dari responden (Wajib Pajak di KPP Pratama Palembang Seberang Ulu) menggunakan kuesioner dengan skala likert yang digunakan untuk mengatur Kepatuhan Wajib Pajak Orang Pribadi dalam pajak penghasilan di KPP Pratama Palembang Seberang Ulu Tahun 2019 (Y), Pengetahuan Pajak (X1), Tingkat Pendidikan (X2). Skala likert berisi lima tingkat jawaban yang akan diberikan yaitu Sangat Setuju (SS), Setuju (S), Kurang Setuju (KS), Tidak Setuju (TS), Sangat Tidak Setuju (STS).

\section{Populasi dan Sampel}

$>$ Populasi

Menurut Sugiyono (2017:119), Populasi yaitu wilayah generalisasi yang terdiri dari : objek atau subjek yang memepunyai kuantitas dan karaktreristik tertentu yang ditetapkan oleh peneliti untuk mempelajari dan kemudian dapat ditarik kesimpulannya.

Populasi dalam penelitian ini adalah Wajib Pajak Orang Pribadi dalam Pajak Penghasilan yang terdaftar di KPP Pratama Palembang Seberang Ulu Tahun 2019. Populasi dalam penelitian ini adalah 17.057 Wajib Pajak Orang Pribadi yang terdaftar di KPP Pratama Palembang Seberang Ulu.

Sampel

Menurut Sugiyono (2017:120), Sampel adalah bagian dari jumlah dan karakteristik yang mewakili dari populasi tersebut.

Teknik pengambilan sampel yang digunakan dalam penelitian ini adalah insidental sampling. Insidental sampling adalah teknik penentuan sampel berdasarkan kebetulan, yaitu siapa saja yang secara kebetulan atau insidental bertemu dengan peneliti dapat digunakan sebagai sampel, bila dipandang orang yang tidak sengaja ditemui cocok sebagai sumber data (Sugiyono,2017:126). Karena populasi dalam penelitian ini sangat banyak yaitu sejumlah 17.057, maka guna 
efisien waktu dan biaya dalam menentukan sampel dapat dilakukan dengan menggunakan rumus perhitungan formula slovin sebagai berikut :

$$
\begin{aligned}
& n=\frac{N}{N d^{2}+1} \\
& n=\frac{17.057}{17.05710^{2}+1}=99,99=100 \text { Sampel (Dibulatkan) }
\end{aligned}
$$

Keterangan :

$n \quad$ : jumlah sampel yang dicari

$N \quad$ : jumlah populasi

$d \quad$ : nilai toleransi 10

1 : angka konstan

(Sugiyono, 2017:128)

\section{Sumber Data}

Berdasarkan sumbernya, data yang digunakan dalam penelitian ini yaitu data Primer. Pengertian dari data primer ialah data yang diperoleh peneliti secara langsung (dari tangan pertama). Data yang digunakan dalam penelitian ini adalah data wajib pajak orang pribadi yang melakukan pembayaran pajak penghasilan tahun 2019 dan data dari responden dengan menggunakan kuesioner.

\section{Teknik Pengumpulan Data}

Pengumpulan data ialah langkah yang sangat penting karena data diperlukan untuk mengetahui dan mendapatkan gambaran permasalahan dari objek yang diteliti, teknik pengumpulan data merupahkan langkah paling strategis dalam penelitian, karena tujuan utama penelitian adalah mendapatkan data (Sugiyono, 2017:308).

Teknik yang digunakan dalam penelitian ini adalah menyebarkan koesioner kepada responden yang sedang duduk di KPP Pratama Palembang Seberang Ulu.

\section{Uji Coba Instrumen}

Sebelum melakukan pengambilan data melalui kuesioner, instrumen penelitian dapat diuji terlebih dahulu dengan melakukan uji validitas dan uji reliabilitas.

a. Uji Validitas Data

Uji validitas ialah untuk mengukur sah atau tidaknya suatu kuesioner. Suatu kuesioner dikatakan valid jika pertanyaan dalam kuesioner mampu untuk mengungkapkan sesuatu yang akan diukur oleh kuesioner tersebut (Noor, 2011:169). Untuk mempercepat dan mempermudah proses penelitian ini pengujian validitas dilakukan dengan bantuan komputer dengan menggunakan program SPSS dengan metode korelasi (Pearson Correlation) untuk mencari koesioner korelasi antara variabel $\mathrm{X} 1$ dan $\mathrm{Y}$, Variabel $\mathrm{X} 2$ dan $\mathrm{Y}$, Variabel $\mathrm{X} 1$, $\mathrm{X} 2$ dan $\mathrm{Y}$. Pengujian validasi dilakukan dengan mengkorelasikan masingmasing item skor dengan total skor. Menurut Sarwono (2015:249), pengambilan keputusan dalam uji validitas corrected item total correlation pada singnifikansi $5 \%$ dapat didasarkan pada ketentuan sebagai berikut :

$>$ Jika nilai $r_{\text {hitung }}>r_{\text {tabel }}$ Product moment maka butir soal kuesioner dinyatakan valid.

$>$ Sementara, jika nilai $r_{\text {hitung }}>r_{\text {tabel }}$ Product Moment maka butir soal kuesioner dinyatakan tidak valid. 
b. Uji Reliabilitas

Reliabilitasi adalah alah ukuran suatu kestabilan dan konsistensi instrumen untuk menjawab hal-hal yang berkaitan dengan konstruk-konstruk pertanyaan yang merupakan dimensi suatu variabel dan disusun dalam bentuk kuesioner. Pada penelitian ini digunakan metode pengukuran reliabilitas Cronbanch's Alpha. Pengujian keandalan pengukuran dengan menggunakan Alfa Cronbanch ini adalah koefisien keandalan yang menunjukkan seberapa baiknya item atau butir dalam suatu kumpulan secara positif berkorelasi satu sama lain (Noor, 2011:165). Menurut Sujarweni (2014:192), kuesioner dikatakan reliabel jika Cronbach Alpha > 0,60 maka reliailitas sempurna.

\section{Teknik Analisis Data}

$>\quad$ Uji Asumsi Klasik

a. Uji Normalitas

Priyatno (2014:145), Uji normalitas dipakai untuk menguji apakah nilai residual yang dihasilkan dari regresi terdistribusi secara normal atau tidak. uji Normalitas dipakai peneliti ialah untuk mengetahui kebenaran dari selembaran data yang diperoleh, sehingga dilakukan uji normalitas kepada data yang berhubungan. Kreteria yang dipakai yakni : titik-titik harus menyebar disekitar garis diagonal dan mengikuti arah garis diagonal jika hal ini sesuai dengan dasar pengambilan keputusan ini maka model regresi ini memenuhi asumsi normalitas. Dasar pengambilan keputusan dalam uji Normalitas K-S :

1. Jika nilai Signifikan (Sig) lebih besar dari 0,05 maka data penelitian berdistribusi normal.

2. Sebaliknya jika nilai Signifikan (Sig) lebih kecil dari 0,05 maka data penelitian tidak berdistribusi normal.

b. Uji Heteroskedastisitas

Priyatno (2014:147), Heteroskedastisitas ialah keadaan dari model regresi terjadi varian dariresidual yg tidak sama pada semua pengamatan di model regresi. Bentuk regresi yg baik ialah tidak terjadi heteroskedastisitas.

Menurut Korelasi Spearman kreteria yang digunakan adalah :

1. Titik-titik data penyebar di atas dan di bawah atau di sekitar angka 0.

2. Titik-titik tidak mengumpul hanya diatas atau dibawah saja.

3. Penyebaran titik-titik data tidak membentuk pola bergelombang melebar kemudian menyempit dan melebar kembali.

4. Penyebaran titik-titik dan tidak berpola.

c. Uji Multikolinearitas

Priyatno (2014:147), Multikolinearitas ialah keadaan dimana ditemukannya korelasi sempurna atau mendekati sempurnah antara variabel independen. Bentuk regresi yang baik ialah seharusnya sempurna atau mendekati sempurna diantara variabel bebas.

Pedoman keputusan berdasarkan Nilai Tolerance :

$>$ Jika nilai tolerance $>0,10$ maka artinya tidak terjadi uji multikolinieritas dalam model regresi.

Jika nilai Tolerance $<0,10$ maka artinya terjadi uji multikolinieritas dalam model regresi. 
Pedoman keputusan berdasarkan Nilai VIF (Variance Inflation Factor) :

$>$ jika nilai $\mathrm{VIF}<10,00$ maka artinya tidak terjadi multiklinieritas dalam model regresi.

> Jika nilai VIF > 10,00 maka artinya terjadi multikoliniritas dalam model regresi ini.

\section{Kreteria Pengujian Hipotesis}

a) Analisis Regresi Linear Berganda

Menurut Priyatno (2018:107), analisis ini digunakan untuk menentukan ketepatan prediksi apakah ada hubungan yang kuat antara variabel bebas $(X)$ yakni, pengetahuan pajak (X1), tingkat pendidikan (X2) dengan variabel terkait $(\mathrm{Y})$ kepatuhan wajib pajak orang pribadi. Persamaan umum regresi linear berganda adalah :

Dimana:

$$
Y=a+b_{1} X_{1}+b_{2} X_{2}+e
$$

$$
\begin{aligned}
& Y=\text { Kepatuhan Wajib Pajak } \\
& a=\text { Konstanta } \\
& b_{1}=\text { Koefisien Pengetahuan Wajib Pajak } \\
& b_{2}=\text { Koefisien Tingkat Pendidikan } \\
& X_{1}=\text { Pengetahuan Wajib Pajak } \\
& X_{2}=\text { Tingkat Pendidikan } \\
& e=\text { Standar eror off the estimat }
\end{aligned}
$$

(Priyatno, 2018:107)

b) Uji Parsial (t-tst)

Priyatno (2018:121), yakni uji t dipakai untk mengetahuii apakah variabel independen secara parsial berpengaruh terhadap variabel dependent. Dengan kreteria berdasarkan Nilai Singnifikansi (Sig) :

$>\quad$ Jika nilai singnifikan $(\mathrm{Sig})<$ protabilitas 0,05 maka ada pengaruh variabel bebas $(\mathrm{X})$ terhadap variabel terikat $(\mathrm{Y})$ atau hipotesis diterima.

$>\quad$ Jika nilai singnifikan $(\mathrm{Sig})>$ protabilitas 0,05 maka tidak ada pengaruh variabel bebas $(\mathrm{X})$ terhadap variabel terikat $(\mathrm{Y})$ atau hipotesis ditolak.

c) Uji Silmultan (F-test)

Uji $F$ digunakan untuk menguji singnifikansi pengaruh variabel bebas $(X)$ secara silmultan terhadap variabel terkait $(Y)$ (Priyatno, 2018:119). Dengan kreteria berdasarkan Nilai Singnifikan (Sig) dari Output Anova :

$>\quad$ Jika nilai Sig $<0,05$, maka hipotesis diterima. artinya Pengetahuan Pajak (X1) dan Tingkat Pendidikan (X2) secara Silmultan berpengaruh terhadap Kepatuhan Wajib Pajak (Y).

$>\quad$ Jika nilai Sig $>0,05$, maka hipotesis ditolak. artinya Pengetahuan Pajak (X1) dan Tingkat Pendidikan (X2) secara Silmultan tidak berpengaruh terhadap Kepatuhan Wajib Pajak (Y).

\section{HASIL PENELITIAN}

\section{Uji Validitas dan Reabilitas Data}

1. Uji Validitas dan Reliabilitas Butir Soal Tingkat Pendidikan di KPP Pratama Pratama Palembang Seberang Ulu. 
TABEL HASIL UJI VALIDITAS DATA PENGETAHUAN PAJAK (X1)

\begin{tabular}{|c|c|c|c|}
\hline $\begin{array}{c}\text { No Butir } \\
\text { Soal }\end{array}$ & r hitung & $\begin{array}{c}\text { r table 5\% } \\
\mathbf{( 3 0 )}\end{array}$ & Kreteria \\
\hline 1 & 0,584 & 0,346 & Valid \\
\hline 2 & 0,693 & 0,346 & Valid \\
\hline 3 & 0,705 & 0,346 & Valid \\
\hline 4 & 0,645 & 0,346 & Valid \\
\hline 5 & 0,750 & 0,346 & Valid \\
\hline 6 & 0,738 & 0,346 & Valid \\
\hline 7 & 0,801 & 0,346 & Valid \\
\hline 8 & 0,586 & 0,346 & Valid \\
\hline 9 & 0,648 & 0,346 & Valid \\
\hline 10 & 0,750 & 0,346 & Valid \\
\hline
\end{tabular}

Berdasarkan perbandingan antara nilai $r$ hitung dengan $r$ tabel, maka dapat disimpulakan bahwa semua butir soal untuk variabel pengetahuan pajak (X1) adalah valid .

TABEL HASIL UJI REABILITAS DATA PENGETAHUAN PAJAK

Cronbach's Alpha $\mathbf{N}$ of ltems

,916 10

Jika alpha > 0.60 maka reliabilitas sempurna, sehingga dari tabel total statistics diatas menunjukkan bahwa setiap item nilai Cronbach Alpha diatas menunjukkan bahwa pertanyaan tersebut cukup reliabel karena nilai cronbach's alpha $>0.60$.

Nilai Cronbach Alpha sebesar 0,916 yang menunjukkan bahwa ke-10 pertanyaan cukup reliabel.

2. Uji Validitas dan Reliabilitas Butir Soal Tingkat Pendidikan di KPP Pratama Pratama Palembang Seberang Ulu.

TABEL HASIL UJI VALIDITAS DATA PENGETAHUAN PAJAK (X1)

\begin{tabular}{|c|c|c|c|}
\hline $\begin{array}{c}\text { No Butir } \\
\text { Soal }\end{array}$ & r hitung & $\begin{array}{c}\mathbf{r} \text { table 5\% } \\
\mathbf{( 3 0 )}\end{array}$ & Kreteria \\
\hline 1 & 0,668 & 0,346 & Valid \\
\hline 2 & 0,700 & 0,346 & Valid \\
\hline 3 & 0,702 & 0,346 & Valid \\
\hline 4 & 0,770 & 0,346 & Valid \\
\hline 5 & 0,720 & 0,346 & Valid \\
\hline 6 & 0,698 & 0,346 & Valid \\
\hline 7 & 0,743 & 0,346 & Valid \\
\hline 8 & 0,688 & 0,346 & Valid \\
\hline 9 & 0,658 & 0,346 & Valid \\
\hline 10 & 0,695 & 0,346 & Valid \\
\hline
\end{tabular}


Berdasarkan perbandingan antara nilai $r$ hitung dengan $r$ tabel, maka dapat disimpulakan bahwa semua butir soal untuk variabel pengetahuan pajak (X1) adalah valid.

TABEL HASIL UJI REALIBILITAS DATA TINGKAT PENDIDIKAN

\begin{tabular}{|r|r|}
\hline Cronbach's Alpha & N of Items \\
\hline, 922 & 10 \\
\hline
\end{tabular}

Jika alpha $>0.60$ maka reliabilitas sempurna, sehingga dari tabel total statistics diatas menunjukkan bahwa setiap item nilai Cronbach Alpha diatas menunjukkan bahwa pertanyaan tersebut cukup reliabel karena nilai cronbach's alpha $>0.60$.

Nilai Cronbach Alpha sebesar 0,922 yang menunjukkan bahwa ke-10 pertanyaan cukup reliabel.

3. Uji Validitas dan Reliabilitas Butir Soal Kepatuhan Wajib Pajak di KPP Pratama Pratama Palembang Seberang Ulu.

TABEL HASIL UJI VALIDITAS DATA PENGETAHUAN PAJAK (X1)

\begin{tabular}{|c|c|c|c|}
\hline $\begin{array}{c}\text { No Butir } \\
\text { Soal }\end{array}$ & r hitung & $\begin{array}{c}\mathbf{r} \text { table 5\% } \\
\mathbf{( 3 0 )}\end{array}$ & Kreteria \\
\hline 1 & 0,690 & 0,346 & Valid \\
\hline 2 & 0,715 & 0,346 & Valid \\
\hline 3 & 0,751 & 0,346 & Valid \\
\hline 4 & 0,751 & 0,346 & Valid \\
\hline 5 & 0,680 & 0,346 & Valid \\
\hline 6 & 0,667 & 0,346 & Valid \\
\hline 7 & 0,723 & 0,346 & Valid \\
\hline 8 & 0,746 & 0,346 & Valid \\
\hline 9 & 0,723 & 0,346 & Valid \\
\hline 10 & 0,685 & 0,346 & Valid \\
\hline
\end{tabular}

Berdasarkan perbandingan antara nilai $r$ hitung dengan $r$ tabel, maka dapat disimpulakan bahwa semua butir soal untuk variabel pengetahuan pajak (X1) adalah valid.

TABEL HASIL UJI REABILITAS KEPATUHAN WAJIB PAJAK

\begin{tabular}{|r|r|}
\hline Cronbach's Alpha & N of Items \\
\hline, 923 & 10 \\
\hline
\end{tabular}

Jika alpha $>0.60$ maka reliabilitas sempurna, sehingga dari tabel total statistics diatas menunjukkan bahwa setiap item nilai Cronbach Alpha diatas menunjukkan bahwa pertanyaan tersebut cukup reliabel karena nilai cronbach's alpha $>0.60$.

Nilai Cronbach Alpha sebesar 0,923 yang menunjukkan bahwa ke-10 pertanyaan cukup reliabel. 


\section{Uji Asumsi Klasik Uji Normalitas}

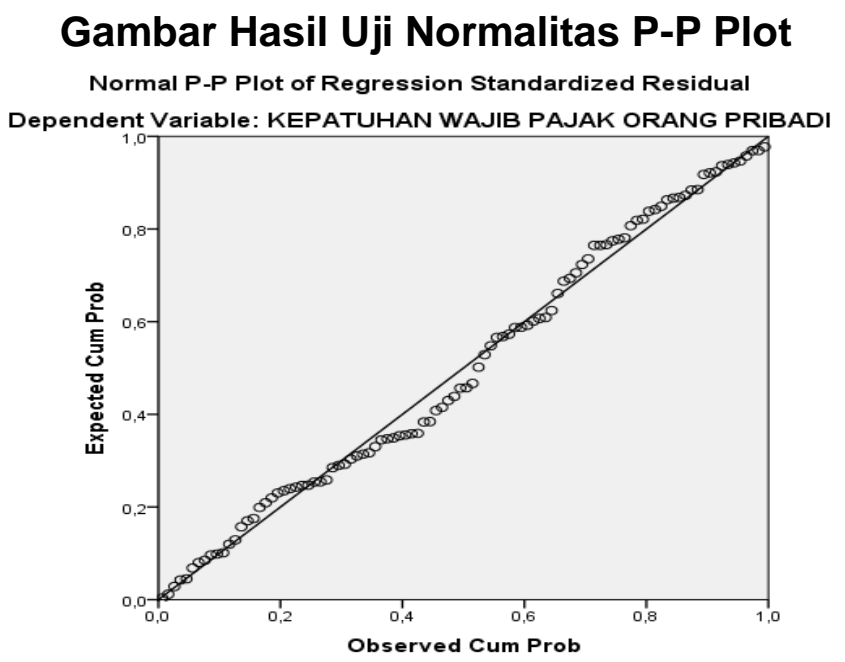

Gambar diatas merupahkan Hasil dari pengelolahan data uji normalitas. Dengan melihat tampilan pada grafik plot terlihat titik-titik menyebar disekitar garis diagonal dan mengikuti arah garis diagonal. Hal ini menunjukkan bahwa model regresi dalam penelitian ini memenuhi asumsi normalitas. Selain menggunakan grafik normal plot, pengujian normalitas didukung dengan analisis statistik menggunakan uji ststistik non-parametrik Kolmograv-Smirnov (K-S). Uji K-S ini dilakukan dengan membuat hiptesis sebagai berikut :

Ho : Data residual berdistribusi normal.

$\mathrm{Ha}$ : Data residual tidak berdistribusi normal.

TABEL HASIL UJI NORMALITAS

\begin{tabular}{|c|c|c|c|c|}
\hline & $\mathbf{Y}$ & $\mathbf{X} 1$ & $\mathrm{X} 2$ \\
\hline \multicolumn{2}{|l|}{$\mathrm{N}$} & 100 & 100 & 100 \\
\hline \multirow{2}{*}{$\begin{array}{l}\text { Normal } \\
\text { Parameters }\end{array}$} & Mean & ,0000000 & ,0000000 & ,0000000 \\
\hline & $\begin{array}{l}\text { Std. } \\
\text { Deviation }\end{array}$ & $\begin{array}{r}6,317220 \\
27\end{array}$ & $\begin{array}{r}6,356350 \\
47\end{array}$ & $\begin{array}{r}6,363915 \\
73\end{array}$ \\
\hline \multirow{3}{*}{$\begin{array}{l}\text { Most Extreme } \\
\text { Differences }\end{array}$} & Absolute & 072 & 094 & ,081 \\
\hline & Positive & 072 & ,094 & ,081 \\
\hline & Negative &,- 057 &,- 060 &,- 072 \\
\hline \multicolumn{2}{|l|}{ Test Statistic } & 072, & 094, & 081, \\
\hline \multicolumn{2}{|c|}{ Asymp. Sig. (2-tailed) } & ,200 c,d &, $028^{c}$ & $107^{\mathrm{c}}$ \\
\hline
\end{tabular}
a. Test distribution is Normal.
b. Calculated from data.
c. Lilliefors Significance Correction.
d. This is a lower bound of the true significance.

\section{Sumber : Output SPSS version 22 (data dioleh, 2020)}

Berdasarkan tabel output diatas, diketahui bahwa nilai signifikansi Asiymp.Sig (2-tailed) sebesar $Y=0,200, X 1=0,028$ dan $X 2=0,107$ lebih besar dari 0,05. Maka sesuai dengan dasar pengambilan keputusan dalam uji normalitas kolmogorov-smirnov diatas, dapat disimpulkan bahwa data berdistribusi normal. Dengan demikian, asumsi atau persyaratan normalitas dalam model regresi sudah terpenuhi. 
Besarnya nilai Kolmograv-Smirnov adalah $\mathrm{Y}=0,072$ dan singnifikan $0,200, \mathrm{X} 1$ $=0,094$ dan singnifikan 0,028 dan $\mathrm{X} 2=0,081$ dan singnifikan 0,107 $>\alpha$ (nilai $\alpha$ adalah $5 \%$ ). Hal ini menunjukan bahwa Ho : Data residual berdistribusi normal diterima.

\section{Uji Heteroskedastisitas}

\section{Gambar Hasil Uji Heteroskedastisitas}

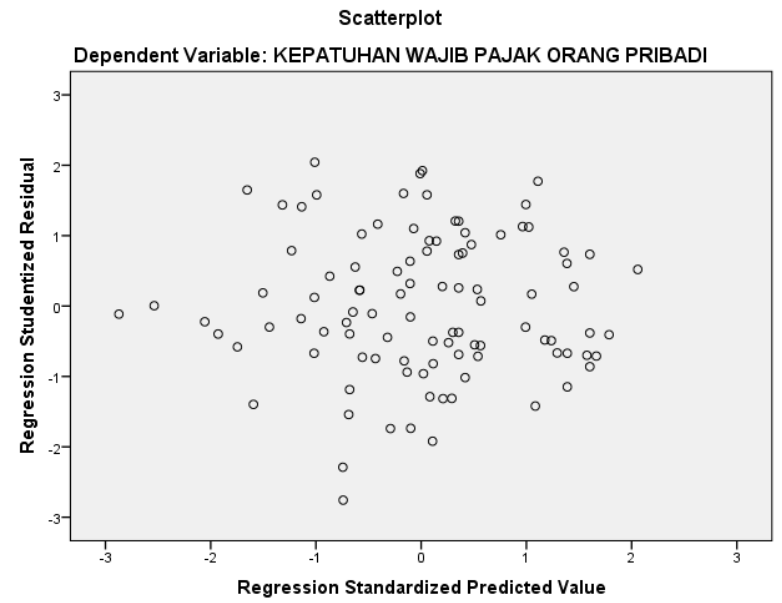

Model regresi yang baik adalah homoskedastisitas atau tidak terjadi heteroskedastisitas yaitu titik-titik pada scatetterplot menyebar diatas dan dibawah atau disekitar 0 serta tidak membentuk pola tertentu.

Berdasarkan output Scatterplots diatas diketahui bahwa :

1. Titik-titik data penyebar di atas dan di bawah atau di sekitar angka 0.

2. Titik-titik tidak mengumpul hanya diatas atau dibawah saja.

3. Penyebaran titik-titik data tidak membentuk pola bergelombang melebar kemudian menyempit dan melebar kembali.

4. Penyebaran titik-titik dan tidak berpola.

\section{Uji Multikolinearitas}

TEBEL HASIL UJI MULTIKOLINEARITAS

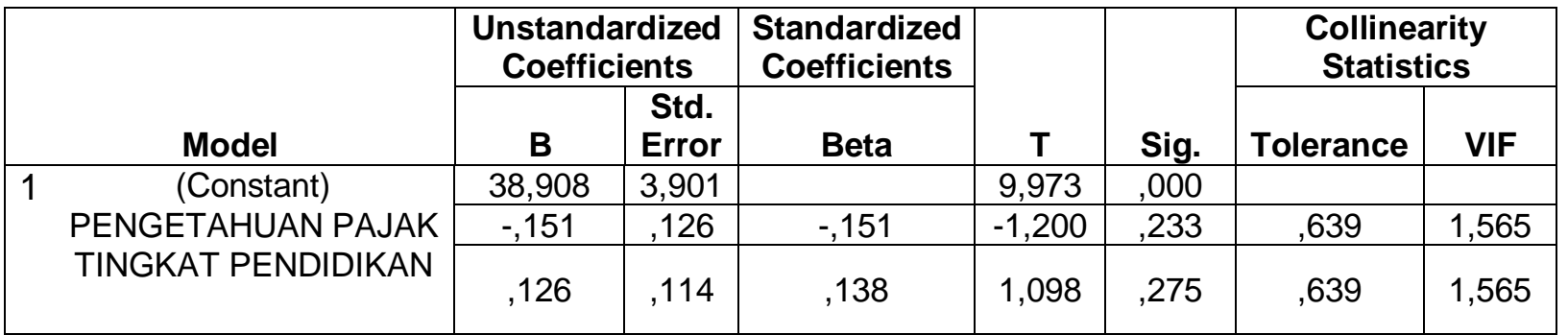

Sumber : Output SPSS version 22 (data dioleh, 2020)

Berdasarkan tabel output "Coefficients" pada bagian "Collinearity Statistics" diketahui nilai Tolerance untuk variabel Pengetahuan Pajak (X1) dan Tingkat Pendidikan (X2) adalah 0,639 lebih besar dari 0,10. Sementara nilai VIF untuk variabel Pengetahuan Pajak (X1) dan Tingkat Pendidikan (X2) adalah 1,565 < 10, 
00. Maka mengacu pada dasar pengambilan keputusan dalam uji multikolinearitas dapat disimpulkan bahwa tidak terjadi gejala multikolinearitas dalam model regresi.

\section{Pengujian Hipotesis}

\section{Uji Regresi Linear Berganda}

TABEL HASIL UJI REGRESI LINEAR BERGANDA

\begin{tabular}{|l|l|r|r|r|r|l|}
\hline \multicolumn{2}{|l|}{ Model } & $\begin{array}{c}\text { Sum of } \\
\text { Squares }\end{array}$ & Df & $\begin{array}{c}\text { Mean } \\
\text { Square }\end{array}$ & F & Sig. \\
\hline \multirow{2}{*}{1} & Regression & 67,690 & 2 & 33,845 &, 831 &, $439^{\mathrm{b}}$ \\
\cline { 2 - 7 } & Residual & 3950,820 & 97 & 40,730 & & \\
\cline { 2 - 7 } & Total & 4018,510 & 99 & & & \\
\hline
\end{tabular}

Sumber : Output SPSS version 22 (data dioleh, 2020)

Berdasarkan nilai signifikansi (Sig), dari output Anova diatas adalah sebesar 0,439 . Karena nilai Sig 0,439<0,05, maka sesuai dengan dasar pengambilan keputusan dalam uji $\mathrm{F}$ dapat disimpulkan bahwa hipotesis diterima atau dengan kata lain Pengetahuan Pajak (X1) dan Tingkat Pendidikan (X2) secara simultan berpengaruh terhadap Kepatuhan Wajib Pajak (Y).

Berdasarkan tabel output diatas diketahui nilai $F$ hitung adalah sebesar 0,831 . Karena nilai $F$ hitung 0,831 > F tabel 3,09, maka sebagaimana dasar pengambilan keputusan dalam uji $\mathrm{F}$ dapat disimpulkan bahwa hipotesis diterima atau dengan kata lain Pengetahuan Pajak (X1) dan Tingkat Pendidikan (X2) secara simultan berpengaruh terhadap Kepatuhan Wajib Pajak (Y).

TABEL HASIL PERSAMAAN REGRESI

\begin{tabular}{|c|c|c|c|c|c|}
\hline \multirow[b]{2}{*}{ Model } & \multicolumn{2}{|c|}{$\begin{array}{l}\text { Unstandardized } \\
\text { Coefficients }\end{array}$} & \multirow{2}{*}{\begin{tabular}{|c|}
$\begin{array}{c}\text { Standardized } \\
\text { Coefficients }\end{array}$ \\
Beta
\end{tabular}} & \multirow[t]{2}{*}{$\mathbf{t}$} & \multirow[t]{2}{*}{ Sig. } \\
\hline & B & Std. Error & & & \\
\hline $1 \quad$ (Constant) & 38,908 & 3,901 & & 9,973 & ,000 \\
\hline $\begin{array}{l}\text { PENGETAHUAN } \\
\text { PAJAK }\end{array}$ &,- 151 & , 126 &,- 151 & $-1,200$ & ,233 \\
\hline $\begin{array}{l}\text { TINGKAT } \\
\text { PENDIDIKAN }\end{array}$ & 126, &, 114 & , 138 & 1,098 & ,275 \\
\hline
\end{tabular}

\section{Sumber : Data Primer diolah 2020}

Tabel (Coefficients) memberikan informasi tentang persamaan regresi dan ada tidaknya pengaruh variabel Tingkat Pendidikan dan Pengetahuan Pajak secara parsial (Sendiri-sendiri) terhadap variabel Kepatuhan Wajib Pajak.

Adapun rumus persamaan regresi dalam analisis atau penelitian ini adalah sebagai berikut: 


$$
Y=a+b 1 x 1+b 2 \times 2 \text { atau } Y=38,908-0,151 x 1+0,126 x 2+e
$$

Berdasarkan hasil tabel output "Coefficients" diatas diketahui nilai Signifikansi (Sig) variabel Pengetahuan Pajak (X1) adalah sebesar 0,233. Karena nilai Sig 0,233 $<$ protabilitas 0,05, maka dapat disimpulkan bahwa $\mathrm{H} 1$ atau hipotesis pertama diterima. Artinya ada pengaruh Pengetahuan Pajak (X1) terhadap Kepatuhan Wajib Pajak (Y).

Berdasarkan tabel output "Coefficients" diatas diketahui nilai Signifikansi (Sig) variabel Pengetahuan Pajak (X1) adalah sebesar 0,275. Karena nilai Sig 0,275< protabilitas 0,05 , maka dapat disimpulkan bahwa $\mathrm{H} 2$ atau hipotesis pertama diterima. Artinya ada pengaruh Tingkat Pendidikan (X2) terhadap Kepatuhan Wajib Pajak (Y). Uji t

TABEL UJI t

\begin{tabular}{|c|c|c|c|c|c|c|}
\hline & & \multicolumn{2}{|c|}{$\begin{array}{l}\text { Unstandardized } \\
\text { Coefficients }\end{array}$} & \multirow{2}{*}{$\begin{array}{c}\begin{array}{c}\text { Standardized } \\
\text { Coefficients }\end{array} \\
\text { Beta }\end{array}$} & \multirow[t]{2}{*}{$\mathbf{t}$} & \multirow[t]{2}{*}{ Sig. } \\
\hline \multicolumn{2}{|c|}{ Model } & B & Std. Error & & & \\
\hline \multirow[t]{3}{*}{1} & (Constant) & 38,908 & 3,901 & & 9,973 & ,000 \\
\hline & $\begin{array}{l}\text { PENGETAHUAN } \\
\text { PAJAK }\end{array}$ &,- 151 & ,126 &,- 151 & $-1,200$ & ,233 \\
\hline & $\begin{array}{l}\text { TINGKAT } \\
\text { PENDIDIKAN }\end{array}$ & ,126 & ,114 & ,138 & 1,098 & ,275 \\
\hline
\end{tabular}

\section{Sumber : Data Primer diolah 2020}

Berdasarkan hasil tabel uji t diatas untuk variabel Pengetahuan Pajak diperoleh $t_{\text {hitung }}-1,200$ dengan Sig 0,233. Sesuai dengan kreteria uji t yang lebih ditetapkan, maka dapat diperoleh kesimpulan bahwa $H_{0}$ diterima dan $H_{A}$ ditolak. Dengan demikian Pengetahuan Pajak berpengaruh negatif signifikan terhadap Kepatuhan Wajib Pajak Orang Pribadi.

Berdasarkan hasil tabel uji t diatas untuk variabel Tingkat Pendidikan $t_{\text {hitung }}$ 1,098 dengan tingkat Sig 0,275. Sesuai dengan kreteria uji t yang lebih ditetapkan, maka dapat diperoleh kesimpulan bahwa $H_{0}$ diterima dan $H_{A}$ diterima. Dengan demikian pengetahuan pajak berpengaruh positif singnifikan terhadap Kepatuhan Wajib Pajak Orang Pribadi.

\section{Uji F}

TABEL UJI F

\begin{tabular}{|c|c|c|c|c|c|c|}
\hline \multicolumn{2}{|c|}{ Model } & \begin{tabular}{|c|} 
Sum of \\
Squares
\end{tabular} & Df & $\begin{array}{c}\text { Mean } \\
\text { Square }\end{array}$ & $\mathbf{F}$ & Sig. \\
\hline \multirow[t]{3}{*}{1} & Regression & 67,690 & 2 & 33,845 & ,831 & $439^{b}$ \\
\hline & Residual & 3950,820 & 97 & 40,730 & & \\
\hline & Total & 4018,510 & 99 & & & \\
\hline
\end{tabular}

Sumber : Data Primer diolah 2020 
Berdasarkan tabel output diatas diketahui nilai $F$ hitung adalah sebesar 0,831 dengan tingkat Singnifikan 0,439, artinya nilai signifikan lebih kecil dari taraf signifikan 0,05 atau 0,000 $<0,05$. Hal ini sesuai dengan ketentuan uji $F$ yang telah dijelaskan pada pembahasan sebelumnya, maka dapat disimpukan bahwa $H_{0}$ ditolak dan $H_{1}$ diterima. Artinya secara simultan variabel Tingkat Pendidikan dan Pengetahuan Pajak berpengaruh positif signifikan terhadap Kepatuhan Wajib Pajak Orang Pribadi.

\section{E. PEMBAHASAN}

1. Pengaruh Pengetahuan Pajak terhadap Kepatuhan Wajib Pajak Orang Pribadi Dalam Pembayaran Pajak Penghasilan di KPP Pratama Palembang Seberang Ulu Tahun 2019.

Pengetahuan Pajak berpengaruh negatif dan singnifikan terhadap Kepatuhan Wajib Pajak Orang Pribadi di KPP Pratama Palembang Seberang Ulu tahun 2019. Nilai koefisien regresi yang negatif yaitu sebesar $-0,151$. Nilai $t_{\text {hitung }}$ yang lebih besar dari $t_{\text {tabel }}$ yaitu $-1,200<0,017$. Koefisien determinasi $\left(r^{2}\right) 0,017$ ini berarti Pengetahuan Pajak Mempengaruhi Kepatuhan Wajib Pajak sebesar 1,7\% . besarnya nilai koefisien regresi $-0,151$ dengan nilai konstanta 38,908. Persamaan garis regresinya adalah $Y=38,908-0,151$. Hal ini berarti semakin tinggi Pengetahuan Pajak maka semakin tinggi Kepatuhan Wajib Pajak. Hal ini berarti hipotesis pertama $\left(H_{1}\right)$ Pengetahuan Pajak berpengaruh negatif dan singnifikan terhadap Kepatuhan Wajib Pajak Orang Pribadi di KPP Pratama Palembang Seberang Ulu tahun 2019. Berdasarkan uji hipotesis dapat disimpulkan bahwa variabel Pengetahuan Pajak berpengaruh negatif terhadap Kepatuhan Wajib Pajak Orang Pribadi. sehingga semakin tinggi Pengetahuan Pajak akan semakin patuh Wajib Pajak dalam memenuhi kewajibannya membayar pajak. Pengetahuan itu sendiri antara lain Pengetahuan mengenai ketentuan umum dan tata cara perpajakan, Pengetahuan mengenai sistem perpajakan di Indonesia, dan Pengetahuan mengenai fungsi perpajakan. Pengetahuan Perpajakan merupakan salah satu faktor yang menentukan tingkat Kepatuhan Wajib Pajak pada Kantor Pelayanan Pajak Pratama Palembang Seberang Ulu dalam menjalankan kewajiban perpajakannya.

Pengetahuan Perpajakan, memiliki pengaruh negatif terhadap kepatuhan wajib pajak. Wajib Pajak yang memiliki pengetahuan tinggi terhadap ketentuan umum dan tata acara perpajakan, pengetahuan mengenai sistem perpajakan di indonesia, Pengetahuan mengenai Fungsi Perpajakan akan mempermudah dalam melaksanakan kewajiban perpajakannya. Memahami ketentuan umum dan tata acara perpajakan akan mengurangi kesalahan Wajib Pajak dalam mengisi dan melaporkan Surat Pemberitahuan Pajak (SPT), menghitung jumlah pajak terutang serta menyetorkan pajak.

\section{Pengaruh Tingkat Pendidikan terhadap Kepatuhan Wajib Pajak Orang Pribadi Dalam Pembayaran Pajak Penghasilan (PPh) di KPP Pratama Palembang Seberang Ulu Tahun 2019.}

Tingkat Pendidikan berpengaruh positif dan signifikan terhadap Kepatuhan Wajib Pajak Orang Pribadi di KPP Pratama Palembang Seberang Ulu tahun 2019. Nilai koefisien regresi yang positif yaitu sebesar 0,126 . Nilai $t_{\text {hitung }}$ yang lebih besar dari $t_{\text {tabel }}$ yaitu $1,098>0,017$. Koefisien determinasi 0,017 berarti tingkat pemahaman perpajakan mempengaruhi Kepatuhan Wajib Pajak sebesar 1,7\%. Besarnya nilai koefisien regresi 0,126 dengan nilai konstanta 38,908. Persamaan 
garis regresinya adalah $Y=0,126+38,908$. Hal ini berarti semakin efektif Tingkat Pendidikan maka semakin baik Kepatuhan Wajib Pajak. Hal tersebut menunjukkan bahwa Hipotesis kedua $\mathrm{H}_{2}$ diterima yang menyatakan Tingkat Pendidikan berpanguruh positif dan signifikan terhadap Kepatuhan Wajib Pajak Orang Pribadi di KPP Pratama Palembang tahun 2019.

Tingkat Pendidikan mempengaruhi Kepatuhan Wajib Pajak, dimana Tingkat Pendidikan yang efektif dan efisien akan meningkatkan kepatuhan wajib pajak dalam memenuhi kewajiban perpajakannya. Wajib Pajak yang memiliki pendidikan tinggi akan lebih mudah untuk mengerti terhadap ketentuan umum dan tata acara perpajakan, pengetahuan mengenai sistem perpajakan di indonesia, Pengetahuan mengenai Fungsi Perpajakan akan mempermudah dalam melaksanakan kewajiban perpajakannya. Memahami ketentuan umum dan tata acara perpajakan akan mengurangi kesalahan Wajib Pajak dalam mengisi dan melaporkan Surat Pemberitahuan Pajak (SPT), menghitung jumlah pajak terutang serta menyetorkan pajak. diperlukan untuk memberikan efek jera kepada setiap wajib pajak yang tidak patuh dalam memenuhi kewajiban perpajakannya. Hal tersebut juga sangat mempengaruhi kepatuhan wajib pajak dalam memenuhi kewajiban perpajakannya.

\section{Pengaruh Pengetahuan Pajak Dan Tingkat Pendidikan Terhadap Kepatuhan Wajib Pajak Orang Pribadi Dalam Pembayaran Pajak Penghasilan (Pph) Di KPP Pratama Palembang Seberang Ulu Tahun 2019.}

Pengetahuan Perpajakan dan Tingkat Pendidikan berpengaruh negatif, positif dan signifikan secara bersama-sama terhadap Kepatuhan Wajib Pajak Orang Pribadi dalam Pembayaran Pajak Penghasilan di KPP Pratama Palembang Seberang Ulu tahun 2019. Nilai koefisien regresi yangn negatif dan positif yaitu sebesar $-0,151$ untuk variabel Pengetahuan Perpajakan, sebesar 0,126 untuk variabel Tingkat Pendidikan. Nilai $F_{\text {hitung }}$ yang lebih besar dari $F_{\text {tabel }}$ yaitu $0,831>0,17$. Koefisien determinasi 0,017 hal ini berarti Pengetahuan Perpajakan, dan Tingkat Pendidikan mempengaruhi Kepatuhan Wajib Pajak sebesar 1,7\%. Besarnya nilai koefisien regresi sebesar $-0,151$ untuk variabel Pengetahuan Perpajakan dan sebesar 0,126 untuk variabel Tingkat Pendidikan dengan nilai konstanta 38,908. Persamaan garis regresinya adalah $Y=38,908-0,151 X 1+0,126 \mathrm{X} 2$. Hal ini berarti semakin tinggi Pengetahuan Perpajakan dan Tingkat Pendidikan maka semakin tinggi Kepatuhan Wajib Pajak Orang Pribadi dalam Pembayaran Pajak Penghasilan (PPh) di KPP Pratama Palembang Seberang Ulu.

Berdasarkan hasil uji regresi diatas hipotesis ketiga $H_{3}$ diterima, yang menunjukan bahwa Pengetahuan Perpajakan dan Tingkat Pendidikan berpengaruh negatif, positif dan signifikan secara bersama-sama terhadap Kepatuhan Wajib Pajak pada Kantor Pelayanan Pajak Pratama Palembang Seberang Ulu tahun 2019. Kepatuhan dapat dicapai apa bila ada hubungan yang searah antara Pengetahuan Perpajakan dan Tingkat Pendidikan dengan Kepatuhan Wajib Pajak atau dengan kata lain terjadi hubungan timbal balik yang positif antara wajib pajak dan kantor pajak untuk menciptakan kepatuhan, dimana Pengetahuan Perpajakan yang memadai, Serta Tingkat Pendidikan yang tinggi akan berpengaruh signifikan terhadap kepatuhan Wajib Pajak Orang Pribadi di KPP Pratama Palembang Seberang Ulu. 


\section{F. KESIMPULAN DAN SARAN}

1) Kesimpulan

Berdasarkan penjelasan dan analisis data yang telah dilakukan oleh peneliti yaitu mengenai Pengetahuan Pajak dan Tingkat Pendidikan Terhadap Kepatuhan Wajib Pajak Orang Pribadi dalam Pembayaran Pajak Penghasilan (PPh) di KPP Pratama Palembang Seberang Ulu maka dapat diambil kesimpulan sebagai berikut:

a. Pengetahuan pajak berpengaruh negatif dan singnifikan terhadap Kepatuhan Wajib Pajak Orang Pribadi dalam Pembayaran Pajak Penghasilan (PPh) di KPP Pratama Palembang Seberang Ulu Tahun 2019 ditunjukkan dengan persamaan regresi $Y=38,908-0,151 X_{1}$, nilai $t_{\text {hitung }}$ lebih lebih besar dari $t_{\text {tabel }}(0,831>$ $0,17)$ dan dengan koefisien determinasi $r_{\text {square }}\left(r^{2}\right)$ sebesar $1,7 \%$.

b. Tingkat Pendidikan berpengaruh positif dan signifikan terhadap Kepatuhan Wajib Pajak Orang Pribadi dalam Pembayaran Pajak Penghasilan (PPh) di KPP Pratama Palembang Seberang Ulu tahun 2019 ditunjukkan dengan persamaan regresi $Y=38,908+0,126 X_{2}$, nilai $t_{\text {hitung }}$ lebih besar dari $t_{\text {tabel }}(0,831>0,17)$ dan dengan koefisien determinasi $r_{\text {square }}\left(r^{2}\right) 1,7 \%$.

c. Pengetahuan Perpajakan dan Tingkat Pendidikan secara bersama-sama berpengaruh negatif, positif dan signifikan terhadap Kepatuhan Wajib Pajak Orang Pribadi dalam Pembayaran Pajak Penghasilan (PPh) di KPP Pratama Palembang Seberang Ulu tahun 2019 yang ditunjukkan dengan persamaan regresi $Y=38,908-0,151 X_{1}+0,126 X_{2}$, nilai $t_{\text {hitung }}$ lebih besar dari $t_{\text {tabel }}$ yaitu $(0,831>0,17)$ dan dengan koefisien determinasi $r_{\text {square }}\left(r^{2}\right) \quad 1,7 \%$.

\section{2) Saran}

Berdasarkan kesimpulan di atas, maka saran-saran yang dapat diberikan terkait Pengetahuan Perpajakan, Tingkat Pendidikan terhadap Kepatuhan Wajib Pajak Orang Pribadi dalam Pembayaran Pajak Penghasilan (PPh) di KPP Pratama Palembang Seberang Ulu adalah sebagai berikut:

a. KPP Pratama Palembang Seberang Ulu dapat mengadakan kegiatan untuk meningkatkan kepatuhan Wajib Pajak, seperti melakukan penyuluhan atau sosialisasi mengenai pengetahuan perpajakan agar dapat mendorong Wajib Pajak dalam memenuhi angka kepatuhan pajak. Semakin banyak Wajib Pajak yang membayar Pajak, maka akan semakin maju perkembangan baik ekonomi dan infrastruktur lain di indonesia.

b. Dengan tingkat Pendidikan yang sudah cukup relatif baik dapat memudahkan seseorang atau masyarakat untuk menyerap informasi dari Pajak, sehingga dapat meningkatkan kepatuhan Wajib Pajak itu sendiri.

c. KPP Pratama Palembang Seberang Ulu seharusnya dapat bekerja dengan baik dengan mengutamkan kepentingan rakyat khususnya wajib pajak, sehingga kasus-kasus yang sudah terjadi tidak akan terulang dan wajib pajak tidak keberatan untuk membayar pajaknya. Serta penerimaan pajak atas pajak akan meningkat. KPP Pratama Palemang Seberang Ulu Segera dapat memberikan penghargaan (reward) kepada wajib pajak yang patuh dalam menjalankan kewajiban perpajakannya, sehingga tingkat kepatuhan wajib pajak dapat meningkat. 


\section{DAFTAR PUSTAKA}

Chandra, Stefvy. (2017). Pengaruh Pengetahuan Pajak dan Tingkat Pendidikan Terhadap Kepatuhan Wajib Pajak Orang Pribadi Dalam Pembayaran Pajak Penghasilan (PPH) Di KPP Pratama Medan Petisah. Vol. 11 N0. 1 Juni 2017. ISSN No. 2302-2507.

https://drive.google.com/drive/my-drive diakses 29 juni 2020

Hartini, Oki Sri., dan Dani Sopian. (2018) Pengaruh Pengetahuan Perpajakan dan Kesadaran Wajib Pajak Terhadap Kepatuhan Wajib Pajak Terhadap Kepatuhan Wajib Pajak Orang Pribadi (Studi Kasus Pada Pelayanan Pajak Pratama Karees). Jurnal Sains Manajemen \& Akuntansi. Volume X No. 2 / November / 2018.

http://Kpppsu.pajak.go.id/ diakses 6 juni 2020

IBM SPSS Statistics 22

Lubis, Rahmad Hidayat. (2018). Pajak Penghasilan-Teori Kasus dan Aplikasi. Yogyakarta: C.V Andi Offset.

Noor, Juliansyah. (2011). Metodologi Penelitian : Skripsi, Tesis, Disertasi, dan Karya IImia. Jakarta: Prenadamedia Group.

Priyatno, Duwi. (2014). SPP 22 Pengelola Data Praktis. Yogyakarta: Andi.

. (2018). SPSS Panduan Mudah Olah Data Bagi Mahasiswa Dan Umum. Yogyakarta: Andi.

Sugiyono. (2016). Metode Penelitian \& Pengembangan Research and Development. Yogyakarta: Alfabeta, cv.

_ (2017). Metode Penelitian Kombinasi (mixed methods). Bandung: Alfabeta.

V. Wiratna Sujarweni. (2014). Metodologi Penelitian Bisnis dan Ekonomi (Cetakan Pertama). Yogyakarta: Pustaka Baru Press.

TMbooks. (2016). Perpajakan-Esendi dan Aplikasi. Yogyakarta: C.V Andi Offset. www.pajak.go.id diakses 6 juni 2020 